\title{
ANALYSIS OF THE POTENTIAL FOR TOURISM ATTRACTION IN THE DISTRICT KETAPANG SAWI ISLAND, WEST KALIMANTAN
}

\author{
Elen Giantino. \\ The International Bali Tourism Institute \\ egiantino@yahoo.co.id
}

\begin{abstract}
The background of this study was to determine the potential Sawi Island in detailing on the side is still very limited facilities and infrastructure on the island Sawi. This study aims to determine the potential on the island Sawi so as to identify the weaknesses and advantages of tourism Sawi Island. Data collection techniques used were interviews, observation and documentation. The analysis technique used is descriptive qualitative analysis. Results from the study showed there is a lack of completeness of infrastructure, facilities and infrastructure on the island Sawi. Given this research is expected to help stakeholders as supporting data for developing Sawi Island neighborhood.
\end{abstract}

Keywords: Potential Travel Attractions Island Sawi

\section{INTRODUCTION}

Sawi Island is one of the tourist attraction in Kalimantan. Sawi island located in Ketapang, West Kalimantan Province which has an area of 500 hectares with a distance of about 2 to 3 hours drive from the city of Ketapang. The potential of the island Sawi is potential for marine tourism and nature seen from the diversity of coral reefs and rare turtles are diverse habitats such as leatherback, green and hawksbill turtles. In addition, there is a fishing village at the renjong in Mekar Utama. Renjong is a type of crab that can easily be found in the coastal village of Mekar Utama and around the island Sawi. Renjong itself has been exported by the local community to the neighboring countries.

According to the results of interviews with the Tourism Office of Ketapang in 2016, Sawi Island been unveiled as a tourist attraction in 2009. The report traffic levels from 2012 to 2014. Domestic tourists in 2012 amounted to 8,913 tourists and foreign tourists amounted to 132 tourists, in 20136813 amounted to travelers and foreign tourists amounted to 339 travelers. In 2014 tourist arrivals totaled 3,315 domestic and foreign tourists amounted to 224 travelers.

Sawi island that has the potential of marine and underwater natural beauty is now threatened by the waste from PT. Well Harvest Winning. Many people complain about the condition of polluted water so feared could damage marine ecosystems particularly negative impact on local people who work as nelayan. Condition of threatened water and abrasion factors that erode the coast of the 
island Sawi is also a potential threat that could undermine Tourist Attractions Sawi Island.

Some of the activities that have been carried out by government agencies to increase tourist arrivals to the island Sawi such as setting up a homestay and do a promotional tour through exhibitions such as in Jakarta and Bali. Lack of government attention to the accessibility around the island Sawi, tourists who want to visit the island Sawi, tend to kesulitandikarenakan facilities and inadequate infrastructure such as trouble finding the travel and transportation to the site, and tourists have trouble finding information on marine transportation, the purpose of this study is untukmengetahui the potential contained Sawi the Island so as to increase the number of tourists, local people's welfare and attracting investors, especially in the field of tourism.

\section{LITERATURE THEORY REVIEW}

\section{Tourism development}

The development of tourism in general can be summed up as a strategy that aims to meingkatan development of products and services that can benefit the people around tourism and government. The key elements that need attention in order to support the development of tourism in the tourist destination that involves the planning, implementation and development includes the construction of five elements (Suwantoro, 2012: 19-25) that is a tourist attraction and appeal, tourist infrastructure, tourist facilities, governance or infrastructure and community / environment.

\section{Tourism potential}

The conclusion of the tourism potential is everything contained in tourist locations that can also be seeded from the point of either natural or the result of the work of man himself.

\section{Marine tourism}

Definition of nautical tourism in general is carried out tourism activities in the lake, beach and sea and inseparable from the existence of ecosystems that are rich in marine life in addition to the usual tourist packages offered

\section{Natural tourism}

Development should take into account the nature of the natural environment, the built and social good in terms of the potential that can be utilized and in terms of those limitation are the limitations of the natural environment aspects tersebut.Pembangunan infrastructure done with consideration of environmental adaptation (back to nature), control through the analysis of the environmental impact, setting the visitors by taking into account the carrying capacity of the facilities and infrastructure

\section{RESEARCH METHODS}

The study was conducted on the island Sawi, located in Mekar Utama Village , Ketapang, West Kalimantan. The boundaries of the area of Ketapang based sources of www.pontianak.bpk.go.id accessed on 12 March 2016 are: 
North: Pontianak district, the district, Sekadau and Melawi

South: Java Sea

West: District Kayong Karimata Strait and the North and the Natuna Sea

East: Central Kalimantan Province and Melawi

This study was conducted from January to May. In January to March terkonsetrasi research in Chapter 1 to Chapter 3 and field research conducted in April. Furthermore, researchers complements Chapter 4 and Chapter 5 through May. Qualitative data is data type Object and Fascination in Ketapang and data on the number of tourist arrivals while Quantitative Data, in the form of data on the number of accommodation, the number of facilities and supporting infrastructure in the island Sawi, nor the number of tourist visits.

Sources of primary data, ie data obtained from the first data source or directly obtained from a study Sawi Island, both of questionnaire data as well as orally or in writing of the respondenataupun informants. For example the source data obtained from community leaders, government agencies, tourism businesses and tourists.

Data collection techniques such as interviews, observation and documentation while the technique of analysis of data collected from interviews, observation data from literature sources, analyzed using qualitative descriptive analysis.

\section{CONCLUSION}

Development of places and attractions in Ketapang until the last decade is still in the category of less developed. This reality occurs due to the relatively few existing attractions, unique constraints, as well as limited facilities and infrastructure to support tourism provided.

Sawi Island has the potential for marine tourism and unspoiled nature and can be developed as an ecotourism opportunities. One of the potential in the island is the island Sawi Sawi can be used as a conservation and breeding turtles pearl. Sawi island layout that is not so far from the island Cempedak, can be used as an alternative when visiting tourist visit Sawi Island. The majority of people around the island Sawi was fishing with marine products that are often found around the village of Mekar Utama is Renjong, a type of crab that is often used as a local culinary and have been exported to the neighboring country.

Top Mekar village is a crossing location for travelers who want to cross to the island Sawi. If travelers to the village of Mekar Utama from Ketapang City, then the tourists will first pass through the village of Pesaguan then reached the village of Mekar Utama. Top Mekar village is the village which is crossed by the river called Sungai Tengar the village in question is better known by local people as Tengar River Village.

Homestay or Shelter in Mekar Utama shopping center, Community Health Center (Puskesmas), places of worship and educational facilities only in Mekar Utama, it is because the island Sawi just a fishing island stopover place and not have a resident community tetap.Apabila locals and tourists who come to visit require more adequate facilities, then all kinds of amenities are included in the city of Ketapang.

Sawi Island is located in a strategic area, which can be reached from the direction of Central Kalimantan, Kendawangan and Ketapang City. The path 
towards the island Sawi quite interesting because tourists will pass through air, land and sea. The air line for tourists who come from outside the city can reach Kota Ketapag Ketapang by plane, then the journey continued using the vehicle to Mekar Utama and the last use of the local fishing boats for crossing to the island Sawi.

Impassable road towards the village of Mekar Utama experiencing a lot of damage. In addition to the many holes in the road, the condition also worsened during the rainy season arrives. Long journey takes also into the impact of damage to the road. Almost $10 \mathrm{~km}$ along the way that will be passed after the village of Pesaguan damaged. Damage to reach the $10 \mathrm{~km}$ road, it makes people crossing takes about 1 hour drive. There are no signs of improvement in the way today, but based Tribune Pontianak, road improvements will be carried out this year with budget funds reached $\mathrm{Rp} 15$ billion.

Homestay is one of the supporting facilities located on the island of mustard. Homestay located on the island of Sawi is a relief that diberikanoleh Office of Marine Ketapang. Homestay is free to use by any traveler is equipped with two bathrooms and two empty space as a place to stay. The homestay Unfortunately today become unkempt, overgrown with wild plants around it, the algae on the broken door, plus a lot of tourists who lack awareness of hygiene homestay leaving rubbish strewn across it.

Homestay clean environment that is not necessarily impact on the interest of tourists who visit, especially tourists who want to spend the night on the island Sawi. Plumpness tourists prefer setting up a tent on the shore and some are choosing not to spend the night on the island Sawi. It is seen from homestay conditions that are rarely used and not maintained.

Fishermen around the island Sawi participate in tourism activities as a provider of the crossing from Mekar Utama to the island Sawi. In terms of the provision of crossing, the local community also provides travel packages to Island Sawi, such as overnight packages on the island of mustard, snorkeling and diving. There is also a nursery groups pearl among the local community that became a sideline some local fishermen on the island Sawi. Local government also provides socialization like pearls along the way nurseries do controlling a period of time to the island Sawi.

People on the Sawi Ssland are people who come from Mekar Village Primary majority of livelihood as a result fishermans. Renjong is a type of crab that is very easily found around the Main DesaMekar and to the islands of mustard. Means torch Island Sawi until today still rely on the assistance of the Department of Tourism of Ketapang in the form of lighting that comes from solar energy while the availability of fresh water on the island Sawi still rely on water from artesian wells.

The majority of the island Sawi or Mekar Utama inhabited by ethnic Malay. Some of the cultural arts practiced by the Malay community is like their traditional fishing and a variety of Malay art Kayung. According M.Dardi (2008) in his book entitled "Culture, Customs and Ketapang Malay Customary Law" which safar bathing ceremony and the ceremony set the shelf ". 


\section{DISCUSSION}

Sawi Island is one of the leading attractions in Ketapang District, which has the potential for marine tourism and nature. Communities around the island Sawi majority livelihood as fishermen who depend on the results of the sea and others who work in firms such as palm oil company and PT. Well Harvest Winning.

As a leading tourist attraction, the island is a spot Sawi diving, snorkeling and fishing in Ketapang. Sawi island not only visited by local tourists, but also foreign tourists. Unfortunately, access to the site Sawi island is still quite difficult because it takes time for the use of land transport and sea transport, plus Sawi Island is the island that could be said to have no permanent residents and only as a temporary stopover for fishermen who sail.

Obstacles faced Sawi island to be developed for the future is still very lack of facilities and infrastructure of tourist activities on the island Sawi. Until now Sawi island itself has not put up the entry fee and the establishment of an organization is not aware that travel is expected to help the development of future Sawi Island. Given this exposure, is expected to clarify the intricacies Sawi Island, so it can be the basis of future development.

\section{REFERENCES}

Admin. 2016. Terminal Kota Ketapang. (Serial Online), (Cited 2016 May 20 ${ }^{\text {th }}$ ) URL : http://www.policenewscenter.com

Anonim. 2015. Definisi Pariwisata. (Serial Online), (Cited 2016 February $2^{\text {th }}$ ) URL : http://23tourism.blogspot.co.id/2015/01/definisi-pariwisata.html

Anonim. 2015. Luas Kabupaten Ketapang. (Serial Online), (Cited 2016 April $28^{\text {th }}$ ) URL : http://disbudparpora.ketapangkab.go.id/imdex.php?lang=en

Anonim. 2016. Kabupaten Ketapang. (Serial Online), (Cited 2016 February $4^{\text {th }}$ ) URL : http://www.humas.ketapang.go.id/

Anonim. 2016. Nelayan di Pulau Sawi. (Serial Online), (Cited 2016 May $4^{\text {th }}$ ) URL : wisatamelayu.com

Anonim. 2016. Pengertian destinasi. (Serial Online), (Cited 2016 March $28^{\text {th }}$ ) URL : http://ferryta.blogspot.co.id/2016/02/pengertian-destinasipariwisata.html

Bambang, Sunaryo. 2012. Kebijakan Pembangunan Destinasi Pariwisata Konsep dan Aplikasinya di Indonesia. Yogyakarta : Gava Media.

BPK. 2016. Republik Indonesia Kalimantan Barat, Wilayah Administrasi Kabupaten Ketapang. (Serial Online), (Cited 2016 February $4^{\text {th }}$ ) URL : http://pontianak.bpk.go.id/?page_id=485\# 
Dardi. 2008. Kebudayaan, Adat Istiadat dan Hukum Adat Melayu Ketapang. Ketapang : Kantor Informasi Kebudayaan dan Pariwisata Kabupaten Ketapang.

Dewi, Oktami. 2013. Konsep Pengembangan. (Serial Online), (Cited 2016 February 2th) URL : http://webchache.googleusercontent.com/

Herdiana, Lisa. 2012. Pengertian Wisata Bahari. (Serial Online), (Cited 2016 February $\left.2^{\text {th }}\right)$ URL : http://lisaherdiana.blogspot.co.id/2012/04/daya-tarikdan-kawasan-wisata.html

Ilham. 2013. Pelabuhan Suka Bangun Ketapang. (Serial Online), (Cited 2016 May $4^{\text {th }}$ ) URL : panoramio.com

Metropolis. 2016. PT. Well Harvest Winning. (Serial Online), (Cited 2016 May $\left.4^{\text {th }}\right)$ URL : pontianakpost.com

Ningsih, Sri. 2012. Sirkuit Pantai Tanjung Batu. (Serial Online), (Cited 2016 May $\left.22^{\text {th }}\right)$ URL : sriningsih201112043.blogspot.com

Soemarno. 2010. Pengertian Wisata Alam. (Serial Online), (Cited 2016 February $\left.2^{\text {th }}\right)$ URL : marno.lecture.ub.ac.id

Suwantoro, Gamal. 1997. Dasar-Dasar Pariwisata. Yogyakarta : Andi Offset.

Yopi. 2015. Bandara Rahadi Oesman Ketapang. (Serial Online), (Cited 2016 May $4^{\text {th }}$ ) URL : anantarakalbar.com

Yudo, Sudarto. Nelayan Pulau Sawi. (serial Online), (Cited 2016 May $4^{\text {th }}$ ) URL : http://yudosudarto.blogspot.com 